\title{
Long-term survival and the viable but nonculturable state as part of the life cycle of Listonella pelagia
}

\author{
Susana Pereira Armada, Rosa Farto, María José Pérez, Teresa Pérez Nieto* \\ Microbiología, Departamento de Biología Funcional y Ciencias de la Salud, Facultad de Ciencias, Universidad de Vigo, \\ Lagoas-Marcosende s/n, 36200 Vigo, Spain
}

\begin{abstract}
Survival of the turbot-virulent strain $7 \mathrm{P}$ of Listonella pelagia was evaluated at 3 incubation temperatures $\left(4,10\right.$ and $\left.22^{\circ} \mathrm{C}\right)$ in microcosms of natural freshwater and defined media of different salinities $(9,16$ and $33 \%)$ and nutrient concentrations $\left(0.005,1\right.$ and $\left.17 \mathrm{~g} \mathrm{l}^{-1}\right)$. During the experimental period, different counting procedures were used to assess the population state. These were: (1) acridine orange total counts (AOTC); (2) nalidixic acid direct counts (NADC); (3) 2-(p-iodophenyl)3-(p-nitrophenyl)-5-phenyl tetrazolium chloride (INT) direct counts (INTDC); and (4) plate counts (PC). Resuscitation of the viable but nonculturable (VBNC) populations was performed both in vitro and in vivo. Electron microscopy and membrane protein profiling of the cells was conducted. Irrespective of the temperatures assayed, $L$. pelagia remained culturable for long periods in the definedmedium microcosms of $33 \%$ and 0.005 or $1 \mathrm{~g} \mathrm{l}^{-1}$ nutrient content, but entered a VBNC state in freshwater, at lower salinities (9 or 16\%) and/or at the highest nutrient content $\left(17 \mathrm{~g} \mathrm{l}^{-1}\right)$. Although, in these cases, cells displayed a spheroid morphology, a significant reduction in size $(p<0.05)$ was only observed in long-term surviving cells. No changes were found in membrane protein profiles. VBNC cells were recovered in vitro in samples that contained less than 0.0001 culturable cells ml ${ }^{-1}$, or that had been treated with ampicilline at bacteriolytic concentrations, and from the internal organs of infected sea bream. The overall results suggest long-term survival of L. pelagia, and that the VBNC state is part of its life cycle.
\end{abstract}

KEY WORDS: Listonella pelagia $\cdot$ Long-term survival $\cdot$ Viable but nonculturable state $\cdot$ In vitro In vivo $\cdot$ Resuscitation

Resale or republication not permitted without written consent of the publisher

\section{INTRODUCTION}

Listonella pelagia (MacDonell \& Colwell 1985), formerly classified as Vibrio pelagius (Baumann \& Baumann 1980), is a marine halophilic bacteria reported to be an opportunistic pathogen affecting various fish and shellfish species (Angulo et al. 1992, Castro et al. 1992, Santos et al. 1997).

Different studies have shown that under certain conditions, marine microorganisms can enter 2 different physiological states (Oliver 1993). Oligotrophic environments, such as oceanic areas, induce the starvation survival response, where the formation of ultramicrocells and the synthesis of 'cross-protective' stress proteins have been demonstrated (Kjelleberg et al. 1993, Fegatella \& Cavicchioli 2000). In the 'viable but nonculturable' (VBNC) state, microorganisms - although they display other measurable life activities - cannot be detected by growth on bacteriological media (Roszak \& Colwell 1987). Whether the VBNC state is a survival strategy against stressful environmental conditions (Oliver et al. 1995, Huq et al. 2000), or a process of deterioration leading to cell death (Desnues et al. 2003), is yet to be determined. The first hypothesis implies reversibility and has to preclude the possibility of regrowth by a few remaining culturable cells. High dilution rates, or inhibitors of these remaining actively growing cells, have been used to address this hypothesis (Lleo et al. 1998). However, (1) controversial resuscitation results have been found even within the same species (Wai et al. 2000, Rahman et al. 2001) and (2) reversal of the inducing factor is not always sufficient to induce a return to culturability and, therefore, recovery conditions may be difficult to 
find. In fact, several reports indicate that the return to culturability is stimulated by autocrine or extracellular factors (Steinert et al. 1997, Biketov et al. 2000). Furthermore, for the VBNC state to be considered as a programmed response, it is necessary to find the genes involved (Chowdbury et al. 1994). Also, oxidative stress has been associated with the VBNC state. After adding hydrogen-peroxide-degrading compounds to resuscitation media, Bogosian et al. (2000) found the apparent recovery of Vibrio vulnificus.

Since the first description of the VBNC state, a reduction in cell size and a morphological change from rod to coccus has been accepted for most (Oliver 2000), if not all, species (Mizunoe et al. 2000, Mary et al. 2002). Moreover, alterations in the cell wall, membrane, cytoplasm, protein, RNA and DNA synthesis have been described (Huq et al. 2000, Oliver 2000, Chaiyanan et al. 2001, Signoretto et al. 2002). The potential virulence of VBNC cells has been demonstrated for various human (Rahman et al. 1994, Pommepuy et al. 1996, Sack et al. 1998), plant (Grey \& Steck 2001) and fish pathogens (Magariños et al. 1994), although in some other cases this could not be verified (Forsman et al. 2000, Hald et al. 2001).

The aim of this work was to assess the influence of different environmental variables on the survival of a turbot virulent strain of Listonella pelagia in order to establish the ability of this opportunistic pathogen to disseminate itself in freshwater and estuarine environments, and to evaluate the possible epizootic risks. Cell populations were characterized by acridine orange total counts (AOTC), nalidixic acid direct counts (NADC), 2-(p-iodophenyl)-3-(p-nitrophenyl)-5-phenyl tetrazolium chloride (INT) direct counts (INTDC) and plate counts (PC). Cells were examined by electron microscopy and their membrane protein profiles studied. Furthermore, the significance of the VBNC in this species was evaluated both by in vitro and in vivo resuscitation assays.

\section{MATERIALS AND METHODS}

Strain and culture conditions. Strain $7 \mathrm{P}$ of Listonella pelagia was isolated from the internal organs of diseased juvenile turbot reared on a fish farm on the Ría de Vigo (NW Spain). The strain showed an $\mathrm{LD}_{50}$ of $9.5 \times$ $10^{4}$ colony-forming units (cfu) after intraperitoneal injection into turbot weighing $5 \mathrm{~g}$ (Angulo et al. 1992). The original strain was preserved by freezing at $-80^{\circ} \mathrm{C}$ in tryptone soy broth (TSB), with a final concentration of $2 \%$ sodium chloride $(\mathrm{NaCl})$ and $15 \%$ glycerol. Routine cultures were obtained on tryptone soy agar (TSA) supplemented with $1.5 \% \mathrm{NaCl}$ (TSA-2\%) for $48 \mathrm{~h}$ at $22^{\circ} \mathrm{C}$. Exponentially growing cells were transferred to flasks containing $200 \mathrm{ml}$ of fresh water or defined

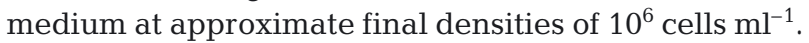
Fresh water was collected from a public fountain in Vigo (chemically untreated; pH 6.16), sterilized through $0.22 \mu \mathrm{m}$ filters and placed into aseptic flasks.

Defined media were composed of nutrient, salts and iron solutions. Three different nutrient and salt concentrations were prepared (modified from Weichart \& Kjelleberg 1996). The nutrient solution was aseptically added to the microcosms to obtain final concentrations of 0.005 , 1 or $17 \mathrm{~g} \mathrm{l}^{-1}$, each containing $49.75 \%$ peptone, $24.88 \%$ yeast extract, $24.88 \%$ glucose and $0.5 \%$ $\mathrm{Na}_{2} \mathrm{HPO}_{4}$. The $33 \%$ microcosms contained $29.4 \mathrm{~g} \mathrm{NaCl}$ $\mathrm{l}^{-1}, 2.4 \mathrm{~g} \mathrm{Na}_{2} \mathrm{SO}_{4} \mathrm{l}^{-1}, 0.1 \mathrm{~g} \mathrm{NaHCO}_{3} \mathrm{l}^{-1}, 0.4 \mathrm{~g} \mathrm{KCl} \mathrm{l}^{-1}$, $0.07 \mathrm{~g} \mathrm{KBr} \mathrm{l}^{-1}, 3.1 \mathrm{~g} \mathrm{MgCl}_{2} \cdot 6 \mathrm{H}_{2} \mathrm{O} \mathrm{l}^{-1}, 0.7 \mathrm{~g} \mathrm{CaCl}_{2} \cdot 2 \mathrm{H}_{2} \mathrm{O}$ $\mathrm{l}^{-1}, 0.013 \mathrm{~g} \mathrm{SrCl}_{2} \mathrm{l}^{-1}$ and $0.013 \mathrm{~g} \mathrm{H}_{3} \mathrm{BO}_{3} \mathrm{l}^{-1}$. The 16 and $9 \%$ microcosms were prepared with $1 / 2$ and $1 / 4$ of these quantities, respectively. The salinities were measured with a portable salinometer (Orion 130). Finally, a filter-sterilized iron solution $\left(\mathrm{FeSO}_{4} \cdot 7 \mathrm{H}_{2} \mathrm{O}\right.$ in $0.4 \mathrm{M}$ tricine) was added at a final concentration of $0.01 \mathrm{mM}$. Survival experiments were performed in duplicate at incubation temperatures of 4,10 or $22^{\circ} \mathrm{C}$ while rotating (100 rpm).

Cell enumeration procedures. At the time of inoculation and at regular intervals after that, samples were removed from microcosms in order to perform the different counting procedures. After colonies could no longer be detected on solid media, direct viable counts (NADC, INTDC) were extended to continue over a period of 1 or more weeks.

AOTC and NADC: Duplicate $0.5 \mathrm{ml}$ aliquots were treated overnight with a final concentration of $0.02 \%$ (w/v) of both nalidixic acid (NA) and yeast extract at $22^{\circ} \mathrm{C}$, while rotating at $100 \mathrm{rpm}$ (modified from Kogure et al. 1979). Samples were then stained with $0.01 \%$ $(\mathrm{w} / \mathrm{v})$ acridine orange (AO) for $2 \mathrm{~min}$ at room temperature and collected in $0.2 \mu \mathrm{m}$ black polycarbonate filters (Millipore), following the indications of Kepner \& Pratt (1994). Total and enlarged cell numbers were determined under blue light excitation with a magnification of $1250 \times$ using an Olympus BH2-RFC fluorescence microscope. Those cells that were elongated by at least 1.5-fold in length and/or width, with respect to nalidixic acid [NA]-untreated cells, were recorded as NA-active cells (Barcina et al. 1995). A total of 40 fields were counted using a $10 \times 10$ ocular grid and, subsequently, the mean cell number per field was determined.

INTDC: Cell suspensions were incubated with a final concentration of $0.01 \%(\mathrm{w} / \mathrm{v})$ of INT for $1 \mathrm{~h}$ at $22^{\circ} \mathrm{C}$ in the dark (modified from Zimmermann et al. 1978). Samples were fixed with a final concentration of $2 \%(\mathrm{w} / \mathrm{v})$ formaldehyde (FMA) and placed in a Neubauer improved counting chamber. Counts were 
performed in duplicate using an Olympus $\mathrm{BH} 2$ microscope (1250× magnification). Cells containing an intracellular reddish-brown formazan crystal were recorded as INT-active.

Plate counts $(\boldsymbol{P C})$ : Culturable cell numbers were determined by duplicate plating of $0.1 \mathrm{ml}$ aliquots from the microcosms on TSA, and on 20- and 4000-fold dilutions of this medium (TSA $1 / 20$ and 1/4000). These media, except for the freshwater and the $9 \%$ microcosms, were amended with 1.5 or $2.8 \% \mathrm{NaCl}$ to mimic the salinity of the 16 or $33 \%$ microcosms. Plates were incubated for a $3 \mathrm{~d}$ period at $22^{\circ} \mathrm{C}$ and the mean number of cfus was determined. Some of the microcosms were stopped after 5 mo when PC had remained almost constant.

Resuscitation experiments. The resuscitation experiments were started once the culturable cell numbers were fixed at a level below $0.1 \mathrm{cfu} \mathrm{ml}^{-1}$. To attain this level, once PC reached 0 by $0.1 \mathrm{ml}$ seeding, cells from $10 \mathrm{ml}$ samples were collected onto sterile $0.2 \mu \mathrm{m}$ cellulose nitrate filters (Albet). These filters were then placed on TSA, TSA $1 / 20$ and TSA $1 / 4000$ (with the appropriate $\mathrm{NaCl}$ concentration) and the plates were incubated for 1 wk at $22^{\circ} \mathrm{C}$.

In vitro assays: Samples of 1 and $2 \mathrm{ml}$ from the microcosms were added in duplicate to tubes containing 9 or $2 \mathrm{ml}$ (double-strength), respectively, of fresh liquid medium. TSB, and the same medium 20- and 4000-fold diluted (TSB 1/20 and TSB 1/4000), with the appropriate $\mathrm{NaCl}$ concentration (as described for TSA), was used. After $1 \mathrm{wk}$ at either 10 or $22^{\circ} \mathrm{C}$ with rotation, the occurrence of turbidity was recorded as a positive recovery result after both re-isolation on suitable solid media and taxonomic characterization according to Montes et al. (1999). The results were compared to the differential features described for Vibrio pelagius (Angulo et al. 1992, Alsina \& Blanch 1994).

To find out whether true recovery took place or not, additional resuscitation assays were carried out following the extinction of culturable cells by dilution or treatment with ampicilline at bacteriolytic concentrations (modified from Lleo et al. 1998). In the first procedure, 10-, 100- and 1000-fold dilutions of the microcosms were prepared. The second procedure was the incubation of microcosm aliquots with $150 \mathrm{\mu g} \mathrm{ml}^{-1}$ of ampicilline (except in the control samples). After $24 \mathrm{~h}$ at $22^{\circ} \mathrm{C}, 3.37 \mathrm{mg} \mathrm{ml}^{-1}$ of penicillinase $(0.3$ benzylpenicillin units per mg of protein) were added. The working ampicilline concentration was obtained by the broth dilution technique, and tested in the media used to prepare microcosms (3 different salinities and nutrient concentrations). Undiluted, diluted, ampicillinetreated and -untreated samples were all subjected to in vitro resuscitation as described above.
In vivo assays: In vivo resuscitation was performed by intraperitoneal injection into sea bream weighing $3 \mathrm{~g}$, using 8 fish per challenge. VBNC cells, normal culturable cells (used as positive control) and cell-free nutrient broth with $2 \% \mathrm{NaCl}$ (NB-2\%; used as negative control) were tested in units of $0.1 \mathrm{ml}$. The aliquots of VBNC cells were taken directly from the microcosms. Normal cultures of Strain 7P obtained in TSA$2 \%$ were resuspended in NB- $\%$ to an absorbance of 0.22 at $595 \mathrm{~nm}$ (approximately $10^{8}$ cells ml-1 ${ }^{-1}$ ). Appropriate dilutions were prepared and the doses, ranging from $2.3 \times 10^{4}$ to $2.3 \times 10^{7}$ cells ml $^{-1}$, were assayed. The fish were monitored for an $11 \mathrm{~d}$ period, after which the internal organs (liver and kidney) of all specimens were sampled. The isolates obtained on TSA-2\% were taxonomically confirmed, as indicated in the previous section.

Cell characterization studies. Aliquots were extracted in duplicate from the microcosms once experiments had stopped (in long-term survival microcosms) or once resuscitation assays began (in VBNC microcosms). Samples were stored at $-20^{\circ} \mathrm{C}$ until use. Normal culturable cells were grown in NB-2\% for $16 \mathrm{~h}$ at $22^{\circ} \mathrm{C}$ and used for comparison purposes. Samples in units of $50 \mathrm{ml}$ were centrifuged at $10000 \times g$ (Centrikon T-124 centrifuge, Kontron Instruments) for 10 min at $4{ }^{\circ} \mathrm{C}$ prior to membrane protein extraction and electron microscopy.

Membrane protein profiling (MPP). Total and outer membrane proteins (TMP and OMP, respectively) were extracted following the method of Crosa \& Hodges (1982). Cells from $50 \mathrm{ml}$ samples were suspended in $3 \mathrm{ml}$ of $10 \mathrm{mM}$ Tris- $\mathrm{HCl}$ buffer ( $\mathrm{pH}$ 8.0) containing $0.3 \% \mathrm{NaCl}$ and sonicated 5 to 7 times for 30 $\mathrm{s}$ at $50 \mathrm{~W}$ (Branson Sonifier 450) in an ice bath. The unlysed cells were collected at $10000 \times g$ (Sigma 3K-30 centrifuge) for $5 \mathrm{~min}$ at $4^{\circ} \mathrm{C}$, and the supernatant fraction was either centrifuged at $30000 \times g$ for $1 \mathrm{~h}$ at $4^{\circ} \mathrm{C}$ to sediment the TMP, or treated with $3 \%(\mathrm{w} / \mathrm{v})$ sodium lauryl sarcosinate prepared in $20 \mathrm{mM}$ Tris- $\mathrm{HCl}$ buffer (pH 8.0) for 20 min at room temperature to obtain OMP, which was then harvested at $53250 \times g$ for $1 \mathrm{~h}$ at $4{ }^{\circ} \mathrm{C}$. TMP and OMP pellets were suspended in $50 \mu \mathrm{l}$ of distilled water and kept at $-20^{\circ} \mathrm{C}$ until use.

Membrane protein samples, together with a low molecular weight protein standard, were boiled for $10 \mathrm{~min}$ in double-strength sample buffer $(20 \%$ [v/v] glycerol, $4 \%[\mathrm{w} / \mathrm{v}]$ sodium dodecyl sulphate, $10 \%[\mathrm{w} / \mathrm{v}] 2-$ mercaptoethanol, $0.005 \%$ [w/v] bromophenol blue). Aliquots containing $2 \mu \mathrm{g}$ proteins were subjected to electrophoresis on $12.5 \%(\mathrm{w} / \mathrm{v})$ SDS-PAGE (Laemmli 1970 ) at $145 \mathrm{~V}$ for $50 \mathrm{~min}$.

Gels were fixed in $20 \%(\mathrm{w} / \mathrm{v})$ trichloroacetic acid for $30 \mathrm{~min}$, and soaked twice in $10 \%(\mathrm{v} / \mathrm{v})$ ethanol and $5 \%$ $(\mathrm{v} / \mathrm{v})$ acetic acid for $5 \mathrm{~min}$. They were shaken in $5 \%$ 
(w/v) glutaraldehyde for $10 \mathrm{~min}$ and soaked in the ethanol and acetic-acid solution for a further $10 \mathrm{~min}$, before being rinsed twice in distilled water, oxidized in $0.025 \%(\mathrm{w} / \mathrm{v})$ sodium dithionite for $1 \mathrm{~min}$, and washed in distilled water. Staining was performed in a silver solution (0.2 g silver nitrate, $75 \mu$ formaldehyde per $100 \mathrm{ml}$ distilled water) for $30 \mathrm{~min}$. After rinsing in distilled water for $1 \mathrm{~min}$, the developing solution was added $(4 \%[\mathrm{w} / \mathrm{v}]$ sodium carbonate, $10 \mu \mathrm{l}$ sodium tiosulphate $(5 \%[\mathrm{w} / \mathrm{v}])$ and $50 \mu \mathrm{l}$ formaldehyde per $100 \mathrm{ml}$ distilled water). Band developing was stopped with $5 \%$ (v/v) acetic acid.

Electron microscopy (EM). Cells from $50 \mathrm{ml}$ samples were suspended in $1 \mathrm{ml}$ PBS and centrifuged at $10000 \times g$ for $10 \mathrm{~min}$ at $4{ }^{\circ} \mathrm{C}$. Cells were fixed with $2 \%$ (w/v) glutaraldehyde in $0.05 \mathrm{M}$ sodium cacodylate buffer for $2 \mathrm{~h}$ at $10^{\circ} \mathrm{C}$, washed twice with the buffer and once with $50 \%(\mathrm{v} / \mathrm{v})$ ethanol. The samples were then placed on cover slips, air-dried and sputtercoated for $2 \mathrm{~min}$. The observations were undertaken using a Philips XL30 microscope. The number of measurements ranged between 25 and 250, according to the availability of cells within the microcosms. Length and width were measured in recorded images using the program Image Tool 2.0. The biovolume was calculated as proposed by Krambeck et al. (1981).
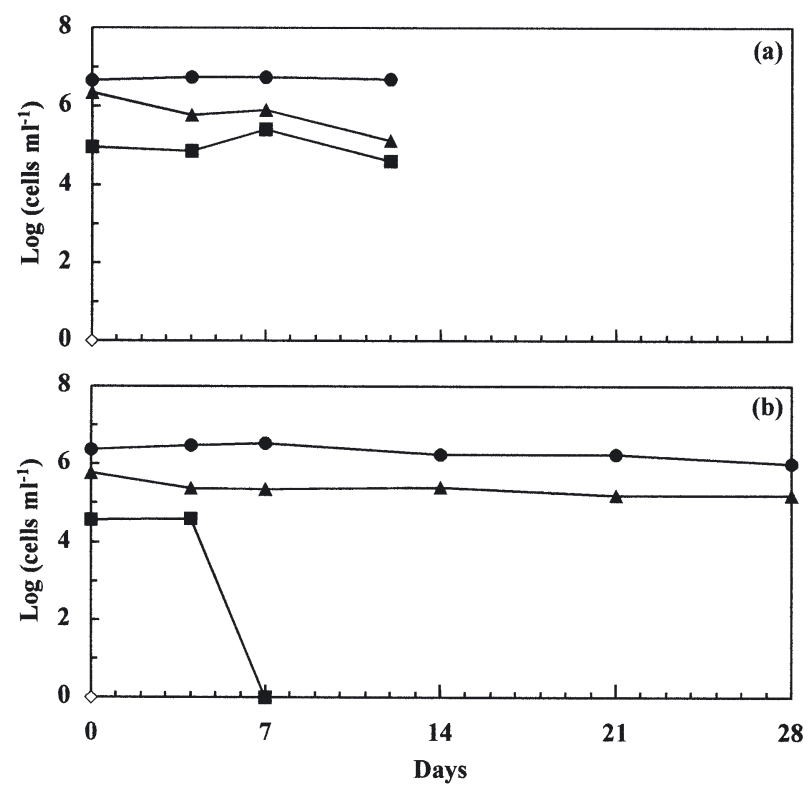

Fig. 1. Listonella pelagia. Survival of Strain $7 \mathrm{P}$ in fresh water at (a) 4 and (b) $22^{\circ} \mathrm{C}$. 口: nalidixic acid direct counts (NADC), $\mathbf{\Delta}$ : INT direct counts (INTDC), $\diamond:$ plate counts (PC). Each value represents the mean from 2 determinations. PC values are means from determinations in 3 solid media (TSA and 20- and 4000-fold diluted TSA). Data are representative of duplicate survival experiments with SD below $12 \%$
Statistical analysis. Statistical analysis was performed using the program SPSS 10.0. Counting procedures were compared 2 by 2 using 1-way ANOVA, including incubation temperature, salinity and nutrient content as co-variables. The influence of these variables on the survival time of the strain was evaluated by regression analysis. The length, width, width:length ratio and biovolume of normal culturable cells and cells from the microcosms were also compared by ANOVA. Probability values equal to or below 0.05 were considered to be statistically significant.

Culture media and chemicals. Culture media or their components were purchased from Cultimed. Ampicilline was obtained from Roche. Tricine, AO, NA, INT, penicillinase, sodium lauryl sarcosinate, glycerol, sodium dodecyl sulphate, mercaptoethanol, bromophenol blue, sodium dithionite and silver nitrate were obtained from Sigma. The protein standard was obtained from BioRad. Other chemicals were analytical grade and purchased from Panreac.

\section{RESULTS}

\section{Analysis of the counting procedures}

The comparison of the different counting procedures revealed that the number of cfu obtained on TSA, TSA $1 / 20$ and TSA $1 / 4000$ was statistically identical. However, when AOTC, INTDC, NADC and PC (the average value obtained for the 3 solid media employed) were compared 2 by 2 , the results were statistically different. AOTC gave the highest yields, followed by INTDC, NADC and PC.

\section{Survival of Listonella pelagia in natural freshwater and defined-medium microcosms}

As Strain 7P displayed homogeneous behaviour in the microcosm duplicates (with overall standard deviations below $12 \%$ ), one of these samples was chosen for graphical representation. When cells of Listonella pelagia were cultured in fresh water, the survival time was $0 \mathrm{~d}$ and a VBNC response could be observed (Fig. 1a). After colonies could no longer be detected on any solid media, continued cell activity was revealed by the 2 direct assays employed, except in fresh water incubated at $22^{\circ} \mathrm{C}$, where NADC dropped below the limits of detection at Day 7 and only respiratory activity was subsequently maintained (Fig. 1b). Table 1 reflects the average survival times of Strain $7 \mathrm{P}$ in the completed defined medium microcosms. The values ranged from 0 to more than $439 \mathrm{~d}$. 
Table 1. Listonella pelagia. Survival time (days, mean value from microcosm duplicates and 2 determinations on the solid media employed) of Strain 7P in the defined media. Microcosms are referred to by their incubation temperature $\left({ }^{\circ} \mathrm{C}\right)$, salinity $(\%)$ and nutrient concentration $\left(\mathrm{g} \mathrm{l}^{-1}\right)$. Those microcosms that were sampled for membrane protein profiling (MPP) and electron microscopy (EM) are indicated. The width-to-length ratio is provided (mean \pm SD) for those cases where changes were statistically significant $(p<0.05)$ and a coccoid morphology was detected. nt: not tested, nf: not found

\begin{tabular}{|c|c|c|c|c|c|}
\hline \multicolumn{3}{|c|}{ Microcosm } & \multirow{2}{*}{$\begin{array}{l}\text { Survival time } \\
\text { (d) }\end{array}$} & \multirow[t]{2}{*}{ Sample } & \multirow{2}{*}{$\begin{array}{l}\text { Width:length } \\
\text { (mean } \pm \text { SD) }\end{array}$} \\
\hline${ }^{\circ} \mathrm{C}$ & $\%$ & $\mathrm{~g} \mathrm{l}^{-1}$ & & & \\
\hline 4 & 9 & 0.005 & 0 & MPP, EM & $0.59 \pm 0.18$ \\
\hline 4 & 9 & 1 & 5 & MPP & nt \\
\hline 4 & 9 & 17 & 0 & MPP & nt \\
\hline 4 & 33 & 0.005 & 37 & MPP, EM & $\mathrm{nf}$ \\
\hline 4 & 33 & 1 & $314^{\mathrm{a}}$ & nt & $\mathrm{nt}$ \\
\hline 4 & 33 & 17 & 21 & nt & nt \\
\hline 10 & 9 & 0.005 & 1 & MPP & nt \\
\hline 10 & 9 & 1 & 1 & MPP & nt \\
\hline 10 & 9 & 17 & 10.33 & nt & nt \\
\hline 10 & 16 & 1 & 42 & MPP, EM & $0.70 \pm 0.16$ \\
\hline 10 & 33 & 0.005 & $439^{a}$ & MPP, EM & $0.60 \pm 0.25^{b}$ \\
\hline 10 & 33 & 1 & $314^{\mathrm{a}}$ & MPP EM & $0.75 \pm 0.16$ \\
\hline 10 & 33 & 17 & 20 & nt & nt \\
\hline 22 & 33 & 0.005 & $153^{\mathrm{a}}$ & MPP, EM & $0.82 \pm 0.17$ \\
\hline 22 & 33 & 1 & $189^{a}$ & nt & nt \\
\hline 22 & 33 & 17 & 15 & nt & nt \\
\hline
\end{tabular}

${ }^{\mathrm{a}}$ Time when counts were stopped in the long-term culturable microcosms

${ }^{\mathrm{b}} \mathrm{p}=0.087$

tered maximum survival time of $10.33 \mathrm{~d}$ (Table 1). NADC decreased below the limits of detection at this time, or after culturability was lost when only INT-active cells were present. However, cells inoculated into $16 \%$ medium (1 g $\mathrm{l}^{-1}$ of nutrient content and cultured at $10^{\circ} \mathrm{C}$ ) demonstrated a longer survival ability (42 d). Thereafter, the values for AOTC, NADC and INTDC remained constant (Fig. 3).

When the defined medium of $33 \%$ and $17 \mathrm{~g} \mathrm{l}^{-1}$ nutrient content was tested, cells became nonculturable and the activities measured by NA and INT assays were maintained (at $4^{\circ} \mathrm{C}$ ), showed a slight decrease (at $10^{\circ} \mathrm{C}$, Fig. $4 \mathrm{c}$ ) or dropped to below detection levels (at $22^{\circ} \mathrm{C}$ ). However, when lower nutrient concentrations (0.005 or $1 \mathrm{~g} \mathrm{l}^{-1}$ ) were assayed (at 33\%), cells, both culturable and active, survived for more than $153 \mathrm{~d}$ (Table 1, Fig. 4a,b). In these cases, a slight decrease both in direct counts and PC was observed as the survival time increased, suggesting that part of the population was being lysed. The only exception to this behaviour was the microcosm cultured at $4^{\circ} \mathrm{C}$ with $0.005 \mathrm{~g} \mathrm{l}^{-1}$ of nutrient content (graph not shown), where cells entered a VBNC state. NADC fell below the detection limits 20 d later than PC, showing a similar pattern to that of the microcosm represented in Fig. 2.

In short, 2 survival responses were detected during the experimental period: either cells re-

PC values dropped to zero at the start of the experiments or soon after inoculation (Fig. 2), at all of the nutrient concentrations assayed for the defined medium of $9 \%$ incubated at 4 or $10^{\circ} \mathrm{C}$, with a regis-

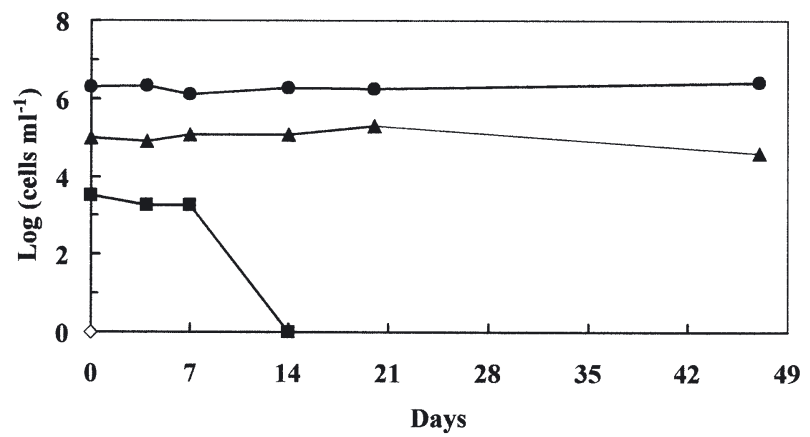

Fig. 2. Listonella pelagia. Survival of Strain $7 \mathrm{P}$ in $9 \%$ and $0.005 \mathrm{~g} \mathrm{l}^{-1}$ (nutrient content) defined-medium microcosm at $4^{\circ} \mathrm{C}$. $\bullet$ AOTC, $\mathbf{\square}$ : NADC, $\boldsymbol{\Delta}$ : INTDC, $\diamond:$ PC. (See Fig. 1 legend for abbreviations.) Each value represents the mean from 2 determinations. PC values are means from determinations in 3 solid media (TSA and 20- and 4000-fold diluted TSA). Data are representative of duplicate survival experiments with SD below $12 \%$ mained culturable and active for long periods (longterm survival) or they entered a VBNC state in which subpopulations differing in their activities were formed.

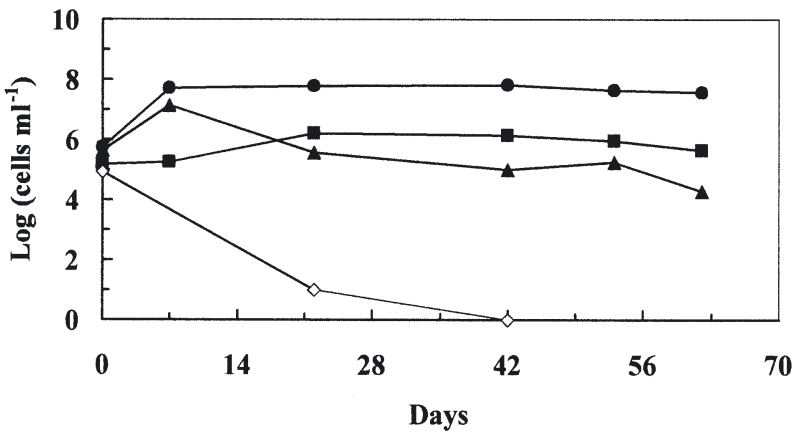

Fig. 3. Listonella pelagia. Survival of Strain $7 \mathrm{P}$ in $16 \%$ and $1 \mathrm{~g}$ $\mathrm{l}^{-1}$ (nutrient content) defined-medium microcosm at $10^{\circ} \mathrm{C}$. AOTC, $\boldsymbol{\square}:$ NADC, $\boldsymbol{\Delta}$ : INTDC, $\diamond:$ PC. (See Fig. 1 legend for abbreviations.) Each value represents the mean from 2 determinations. PC values are means from determinations in 3 solid media (TSA, and 20- and 4000-fold diluted TSA). Data are representative of duplicate survival experiments with SD below $12 \%$ 

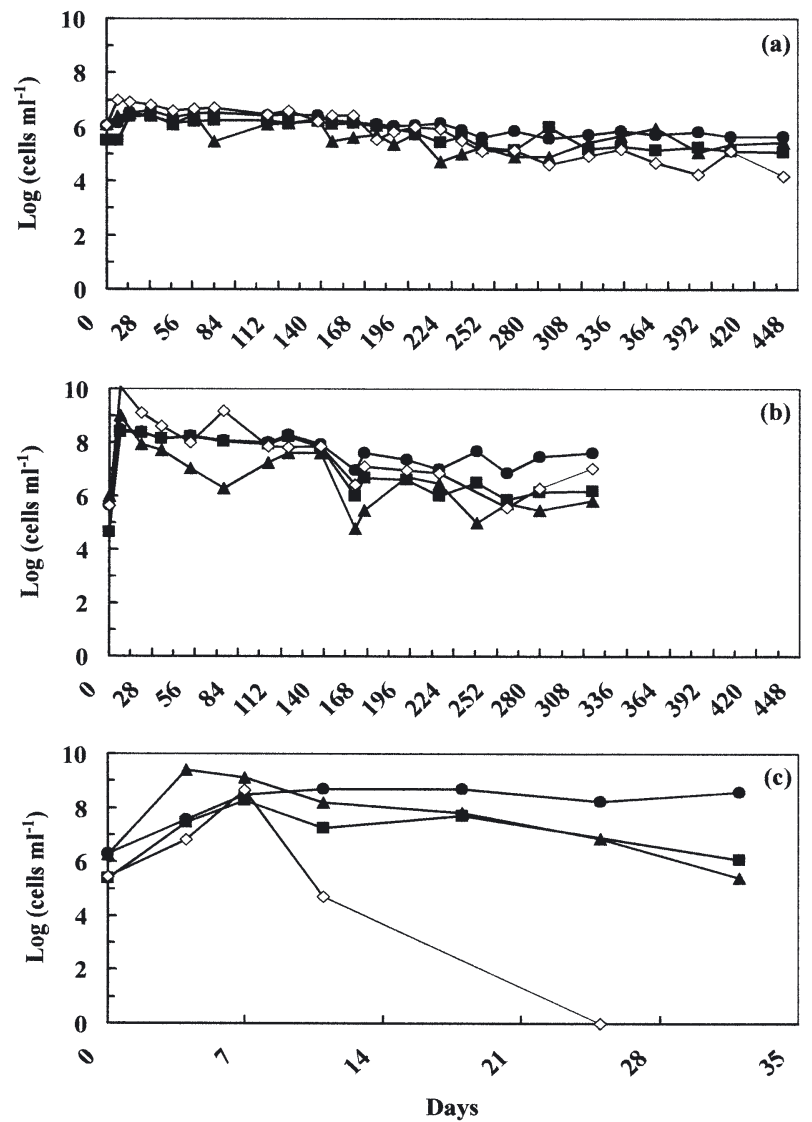

Fig. 4. Listonella pelagia. Survival of Strain $7 \mathrm{P}$ in $33 \%$ and (a) 0.005, (b) 1 and (c) $17 \mathrm{~g} \mathrm{l}^{-1}$ (nutrient content) definedmedium microcosms at $10^{\circ} \mathrm{C}$. $\bullet:$ AOTC, $\mathbf{\sim}$ : NADC, $\mathbf{\Delta}$ : INTDC, $\diamond:$ PC. (See Fig. 1 legend for abbreviations.) Each value represents the mean from 2 determinations. PC values are means from determinations in 3 solid media (TSA, and 20- and 4000fold diluted TSA). Data are representative of duplicate survival experiments with SD below $12 \%$

\section{In vitro resuscitation}

In 4 of the 13 cases where a VBNC state was detected, in vitro resuscitation of 1 or $2 \mathrm{ml}$ undiluted samples was found at $22^{\circ} \mathrm{C}$. When assays were performed at 10 and $22^{\circ} \mathrm{C}$ (see Table 2), in 1 case recovery was only obtained at the higher temperature. Recovery was only detected in TSB medium.

Additional resuscitation assays were performed on these microcosms in the same conditions as previously employed, using up to a 1000-fold dilution (where less than 0.0001 culturable cells $\mathrm{ml}^{-1}$ were present) and treatment with ampicilline at bacteriolytic concentrations. The concentration chosen (150 $\mu \mathrm{g} \mathrm{ml}^{-1}$ ) was able to inhibit $10^{6} \mathrm{cfu} \mathrm{ml}^{-1}$ after incubation for $24 \mathrm{~h}$ at $22^{\circ} \mathrm{C}$, irrespective of the defined medium used. Only in one of the microcosms $\left(10^{\circ} \mathrm{C}, 33 \%\right.$ and $17 \mathrm{~g} \mathrm{l}^{-1}$ nutrient concentration) was true resuscitation confirmed by both dilution and ampicilline assays, as shown in Table 2. The isolates obtained on TSA-2\% from positive tubes displayed the differential features described for Vibrio pelagius: Gram-negative, oxidase-positive, glucosefermenting, growth on TCBS and at different $\mathrm{NaCl}$ concentrations $(0,4$ and $6 \%)$, arginine dihydrolasenegative, ornithine and lysine decarboxylase-negative, indole-positive, gelatinase-positive, arabinosepositive and sacarose acid-positive.

\section{In vivo resuscitation}

Injection of both culturable (positive control) and VBNC cells from 1 out of the 4 microcosms assayed produced haemorrhages in the mouth, base of fins and
However, it was observed that the temperatures studied did not affect the persistence of Listonella pelagia in laboratory microcosms. In fact, the equation obtained by regression analysis confirmed that both the nutrient concentration and salinity, but not the temperatures assayed, were determinants of the average survival time of L. pelagia in the defined medium microcosms:

$T_{\text {surv }}=\mathrm{k}+7.0 \times S-7.6 \times N\left(\mathrm{R}^{2}=0.51\right)$

where $T_{\text {surv }}(\mathrm{d})$ is the mean survival time from microcosm duplicates and 2 determinations on the 3 solid media employed, $S$ is the salinity (\%), $N$ is the nutrient concentration $\left(\mathrm{g} \mathrm{l}^{-1}\right), \mathrm{k}$ is the equation constant and $\mathrm{R}^{2}$ the regression coefficient.
Table 2. Listonella pelagia. In vitro resuscitation of undiluted (1), diluted (1/10, $1 / 100$ and 1/1000), ampicilline-treated and -untreated samples. Microcosms are referred to by their incubation temperature $\left({ }^{\circ} \mathrm{C}\right)$, salinity $(\%$ ) and nutrient concentration $\left(\mathrm{g} \mathrm{l}^{-1}\right)$. Each experiment was performed in duplicate using 2 replicate tubes. Results are shown for the 3 liquid media used (TSB, 20- and 4000-fold diluted $\mathrm{TSB}$, all amended with $\mathrm{NaCl}$ to mimic the salinity of the microcosms) and the different sample volumes inoculated (1 or $2 \mathrm{ml})$, unless otherwise indicated. + : visible turbidity in the tubes and growth on solid media, -: neither visible turbidity nor growth on solid media

\begin{tabular}{|c|c|c|c|c|c|c|c|c|}
\hline \multicolumn{3}{|c|}{ Microcosm } & \multirow{2}{*}{$\begin{array}{c}\text { Undiluted } \\
1\end{array}$} & \multicolumn{3}{|c|}{ Diluted } & \multicolumn{2}{|c|}{ Ampicilline } \\
\hline${ }^{\circ} \mathrm{C}$ & $\%$ o & $\mathrm{g} \mathrm{l}^{-1}$ & & $1 / 10$ & $1 / 100$ & $1 / 1000$ & Untreated & Treated \\
\hline 4 & 9 & 1 & + & - & - & - & + & - \\
\hline 10 & 9 & 1 & + & - & - & - & + & - \\
\hline 10 & 9 & 17 & + & - & - & - & + & - \\
\hline 10 & 33 & $17^{\mathrm{a}}$ & $+^{\mathrm{b}}$ & $++^{\mathrm{b}}$ & $t^{\mathrm{b}}$ & $+t^{\mathrm{b}}$ & $+t^{\mathrm{b}}$ & $t^{\mathrm{b}}$ \\
\hline \multicolumn{9}{|c|}{$\begin{array}{l}{ }^{a} \text { Resuscitation at } 10^{\circ} \mathrm{C} \text { not successful } \\
\text { bIn TSB }\end{array}$} \\
\hline
\end{tabular}


Table 3. Listonella pelagia. In vivo and in vitro resuscitation. Microcosms are referred to by their incubation temperature $\left({ }^{\circ} \mathrm{C}\right)$, salinity $(\%)$ and nutrient concentration $\left(\mathrm{g} \mathrm{l}^{-1}\right)$. NADC: nalidixic acid direct counts, INTDC: INT direct counts, DL: detection limits $\left(8 \times 10^{4}\right.$ cells $\mathrm{ml}^{-1}$ for NADC and $2 \times 10^{4}$ cells ml ${ }^{-1}$ for INT), + : visible turbidity in the tubes and growth on solid media (in vitro assays), or symptoms in fish and re-isolation from internal organs of sea bream (in vivo assays), -: neither visible turbidity nor growth on solid media (in vitro assays), or neither symptoms in fish nor re-isolation on solid media in vivo assays. nt: not tested. For the resuscitation assay, time was measured as days elapsed since the last NADC and INTDC

\begin{tabular}{|rrrccccc|}
\hline \multicolumn{3}{|c}{ Microcosm } & \multicolumn{2}{c}{ Cell count } & \multicolumn{2}{c|}{ Resuscitation assay } \\
${ }^{\circ} \mathrm{C}$ & $\%$ \% & $\mathrm{g} \mathrm{l}^{-1}$ & NADC & INTDC & Time (d) & In vitro In vivo \\
& & & & & & \\
\hline 4 & 9 & 1 & $<\mathrm{DL}$ & $6.5 \times 10^{4}$ & 8 & - & - \\
4 & 33 & 17 & $2.7 \times 10^{6}$ & $7.2 \times 10^{6}$ & 2 & - & + \\
10 & 9 & 1 & $<\mathrm{DL}$ & $3.3 \times 10^{4}$ & 1 & - & $\mathrm{nt}$ \\
10 & 9 & 17 & $<\mathrm{DL}$ & $3.8 \times 10^{5}$ & 0 & - & - \\
10 & 33 & 17 & $1.2 \times 10^{6}$ & $3.5 \times 10^{6}$ & 2 & + & - \\
\hline
\end{tabular}

ished their biovolume either by 72 or $82 \%$ (cells surviving for 153 and 314 d, respectively). However, an increase of $111 \%$ in the biovolume was observed in the $16 \%$ VBNC microcosms.

\section{DISCUSSION}

Two survival strategies for Listonella pelagia are described in this study. Cells remained culturable for periods ranging from $>5$ mo to $>1 \mathrm{yr}$ in the defined media that had salinity and nutrient concentration values closer to those of the marine environment. Survival times of $>1$ yr have been recorded for Vibrio salmonicida (Hoff 1989) and V. vulnificus (Biosca et al. 1996) kept in artificial or natural seawater. However, a VBNC state was detected at the same salinities of estuar-

internal organs of fish, and a pale liver with no apparent necrotic areas (see Table 3). Mortalities were only recorded in fish used as positive controls. Strain 7P was re-isolated from the liver and kidney of all dead or symptomatic fish, and showed the differential features described in the previous section. No isolates were obtained from the internal organs of sea bream that were used as negative controls.

\section{Study of the membrane protein profiles}

No changes were detected in the membrane protein profiles of cells from the 9 microcosms analysed (Table 1), as compared to those of normal culturable cells. However, a $36 \mathrm{kDa}$ protein band proved to be slightly intensified in the total- and outer-membrane protein profiles of the defined medium microcosm of $33 \%, 0.005 \mathrm{~g} \mathrm{l}^{-1}$ nutrient concentration, and $10^{\circ} \mathrm{C}$ incubation, where cells remained culturable after $439 \mathrm{~d}$.

\section{Changes in cell size and shape}

The normal culturable cells of Strain 7P were rodshaped, with average dimensions (mean $\pm-\mathrm{SD}$ ) of 0.55 $\pm 0.31 \mu \mathrm{m}$ width by $1.39 \times 0.99 \mu \mathrm{m}$ length (width:length ratio of $0.43: 0.10)$. In 4 out of the 6 microcosms studied ( 2 of the 3 long-term survival microcosms, and 2 of the 3 showing a VBNC response), cells turned coccoid as shown by a width:length ratio statistically different and closer to 1 than that of culturable cells. In the third long-term culturable microcosm, this ratio was significantly different ( $p=0.087$; Table 1$)$. However, for the first 2 long-term culturable microcosms, cells dimin- ine, or freshwater areas (as described by Eguchi et al. 2000), or when highly nutritive defined media were used.

After the cells of Listonella pelagia failed to form colonies, the populations became heterogeneous, in terms of the activities revealed by nalidixic acid and INT-reduction assays. Although the limits of detection demand the presence of a minimum number of active cells, the different subpopulations detected confirm the relevance of these techniques for the study of the VBNC state (Rahman et al. 1994, Huq \& Colwell 1995). Under certain conditions, the fall of the NADC level below the limits of detection indicates that at least part of the population has lost the ability to uptake substrate. Despite this, respiratory activity was maintained. Consequently, subpopulations found for each microcosm were different and the complete death sequence described for starved Salmonella typhimurium (Joux et al. 1997) was not observed during the experimental period for $L$. pelagia.

To ensure the occurrence of a true recovery and to preclude the possibility of regrowth, resuscitation assays were performed in some of the microcosms using up to a 1000-fold dilution (where less than 0.0001 culturable cells $\mathrm{ml}^{-1}$ would be present), and treatment with ampicilline was carried out at concentrations that would kill actively growing (i.e. culturable) cells. Ravel et al. (1995) demonstrated that recovery in diluted samples containing only $0.085 \mathrm{cfu} \mathrm{ml}^{-1}$ was due to the regrowth of culturable cells. However, in our case a true resuscitation was found in one of the microcosms assayed. Similar results have been reported for Enterococcus faecalis (Lleo et al. 1998). The results suggest incubation temperature has an influence (as reported by Biosca et al. 1996), as any increase was determinant 
on the recovery of VBNC cells. Also, the nutrient concentration of the resuscitation media played a role in this response. The fact that resuscitation was not achieved in all cases indicates that the conditions involved in the exit from the VBNC state are different for each experiment (McDougald et al. 1998), and consequently a positive response in the natural environment cannot be discounted (Weichart et al. 1992).

For in vivo assays (less than $0.01 \mathrm{cfu}$ inoculated into fish), VBNC cells of Listonella pelagia are able to show infectivity and recover culturability after passage through fish. Reproducibility of symptoms would confirm the role of VBNC cells of L. pelagia in disease outbreaks. Similar results have been found for species such as Pasteurella piscicida (Magariños et al. 1994) and Vibrio vulnificus biotype 2 (Marco-Noales et al. 1999).

It appears from our results that the existence of a population with respiratory activity and the ability to uptake substrate is necessary, but not entirely sufficient, to ensure in vitro or in vivo recovery. For example, injection into fish did not always lead to improved recovery conditions, a finding which is contrary to that proposed by Mukamolova et al. (1998).

No changes in the membrane protein profiles of the VBNC cells of Listonella pelagia were detected (the same was found for Pasteurella piscicida by Magariños et al. 1994 and for Aeromonas salmonicida by Effendi \& Austin 1995), whereas a protein band of $36 \mathrm{kDa}$ was slightly intensified in the cell populations surviving $439 \mathrm{~d}$. This indicates a lack of specific membrane protein synthesis during the VBNC process. Moreover, new proteins were found to be present in the outer membrane of the long-term culturable Strain S14 of Vibrio sp. (Kjelleberg et al. 1993).

Examination of cells under EM revealed a spheroid morphology. These changes are in agreement with those reported for Vibrio vulnificus (Oliver, 2000) and starved culturable Yersinia ruckeri (Thorsen et al. 1992), and are assumed to be a survival strategy to optimize substrate uptake by means of an increased surface-to-volume ratio (Lázaro et al. 1999). The reduction in size and biovolume found for long-term surviving cells are in agreement with the changes found for species like $V$. cholerae (Wai et al. 1999) and Photobacterium damselae ssp. damselae (Fouz et al. 1998). However, the increase in biovolume found for VBNC cells of Listonella pelagia cultured in a $16 \%$ medium, and the spheroid morphology, would suggest that although membrane activity is maintained, the cells are under osmotic stress implying an alteration of the cell wall, as reported by Signoretto et al. (2000). Yet in our case it should be pointed out that changes in cell shape and size could not be related to changes in the membrane protein profiles.
In this study the survival strategies of Listonella pelagia in fresh water and different defined media have been described. Both long-term survival and a VBNC state have been observed, confirming the ability of $L$. pelagia to adapt itself to a changing environment. Morphological and size changes were found in longterm culturable and VBNC cells. In at least 1 case the recovery of VBNC cells was confirmed by 2 independent assays. The VBNC cells of $L$. pelagia were recoverable and infective, thus confirming its behaviour as an opportunistic pathogen under certain environmental conditions, indicating potential risk towards the health of aquatic organisms.

Acknowledgements. We are indebted to L. Angulo for providing the strain used in this work. We also thank C. Guisande and E. Armada for their help. This work was supported by the Ministerio de Educación y Ciencia of the Spanish government (project MAR1997-1188-C02-01), the Secretaría Xeral de Investigación e Desenvolvemento of the Xunta de Galicia (grant and projects PGDIT02RMA30102 and PGDIT00MAR 20002PR) and the Universidad de Vigo (grant and projects 64102C023 and 64102C0U8).

\section{LITERATURE CITED}

Alsina M, Blanch AR (1994) A set of keys for biochemical identification of environmental Vibrio species. J Appl Bacteriol 76:79-85

Angulo L, López JE, Lema C, Vicente JA (1992) Vibrio pelagius associated with mortalities in farmed turbot, Scophthalmus maximus. Thalassas 10:129-133

Barcina I, Arana I, Santorum P, Iriberri J, Egea L (1995) Direct viable count of Gram-positive and Gram-negative bacteria using ciprofloxacin as inhibitor of cellular division. J Microbiol Methods 22:139-150

Baumann P, Baumann L (1980) Reevaluation of the taxonomy of Vibrio, Beneckea, and Photobacterium: abolition of the genus Beneckea. Curr Microbiol 4:127-132

Biketov S, Mukamolova GV, Potapov V, Gilenkov E, Vostroknutova G, Kell DB, Young M, Kaprelyants AS (2000) Culturability of Mycobacterium tuberculosis cells isolated from murine macrophages: a bacterial growth factor promotes recovery. FEMS Immunol Med Microbiol 29:233-240

Biosca EG, Amaro C, Marco-Noales E, Oliver JD (1996) Effect of low temperature on starvation-survival of the eel pathogen Vibrio vulnificus biotype 2. Appl Environ Microbiol 62:450-455

Bogosian G, Aardema ND, Bourneuf EV, Morris PJL, O'Neil JP (2000) Recovery of hydrogen peroxide-sensitive culturable cells of Vibrio vulnificus gives the appearance of resuscitation from a viable but nonculturable state. J Bacteriol 182:5070-5075

Castro D, Martínez-Manzanares E, Luque A, Fouz B, Moriñigo MA, Borrego JJ, Toranzo A (1992) Characterization of strains related to brown ring disease outbreaks in southwestern Spain. Dis Aquat Org 14:229-236

Chaiyanan S, Chaiyanan S, Huq A, Maugel T, Colwel RR (2001) Viability of the nonculturable Vibrio cholerae O1 and O139. System Appl Microbiol 24:331-341

Chowdhury MAR, Ravel J, Hill RT, Hug A, Colwell RR (1994) 
Physiology and molecular genetics of viable but nonculturable microorganisms. Microb Ecol 8:105-122

Crosa JH, Hodges LL (1982) Outer membrane proteins induced under conditions of iron limitation in the marine fish pathogen Aeromonas salmonicida. Infect Inmunol 31: 223-227

Desnues B, Cuny C, Grégori G, Dukan S, Aguilaniu H, Nyström T (2003) Differential oxidative damage and expression of stress defense regulons in culturable and nonculturable Escherichia coli cells. EMBO Reports 4:400-404

Effendi I, Austin B (1995) Dormant/unculturable cells of the fish pathogen Aeromonas salmonicida. Microb Ecol 30: 183-192

Eguchi M, Fujiwara E, Miyamoto N (2000) Survival of Vibrio anguillarum in freshwater environments: adaptation or debilitation? J Infect Chemother 6:126-129

Fegatella F, Cavicchioli R (2000) Physiological responses to starvation in the marine oligotrophic ultramicrobacterium Sphingomonas sp. strain RB2256. Appl Environ Microbiol 66:2037-2044

Forsman M, Henningson EW, Larsson E, Johansson T, Sandström G (2000) Francisella tularensis does not manifest virulence in viable but non-culturable state. FEMS Microbiol Ecol 31:217-224

Fouz B, Toranzo AE, Marco-Noales E, Amaro C (1998) Survival of fish-virulent strains of Photobacterium damselae subsp. damselae in seawater under starvation conditions. FEMS Microbiol Lett 168:181-186

Grey BE, Steck TR (2001) The viable but nonculturable state of Ralstonia solanacearum may be involved in long-term survival and plant infection. Appl Environ Microbiol 67: 3866-3872

Hald B, Knudsen K, Lind P, Madsen M (2001) Study of the infectivity of saline-stored Campylobacter jejuni for dayold chicks. Appl Environ Microbiol 67:2388-2392

Hoff KA (1989) Survival of Vibrio anguillarum and Vibrio salmonicida at different salinities. Appl Environ Microbiol 55:1775-1786

Huq A, Colwell RR (1995) A microbiological paradox: viable but nonculturable bacteria with special reference to Vibrio cholerae. J Food Prot 59:96-101

Huq A, Rivera ING, Colwell RR (2000) Epidemiological significance of viable but nonculturable microorganisms. In: Colwell RR, Grimes DJ (eds) Nonculturable microorgamisms in the environment. ASM Press, Washington, DC, p 301-323

Joux F, Lebaron P, Trossellier M (1997) Succession of cellular states in a Salmonella typhimurium population during starvation in artificial seawater microcosms. FEMS Microbiol Ecol 22:65-76

Kepner RL, Pratt JR (1994) Use of fluorochromes for direct enumeration of total bacteria in environmental samples: past and present. Microbiol Rev 58:603-615

Kjelleberg S, Flärdh KGB, Nyström T, Moriarty DJW (1993) Growth limitation and starvation of bacteria. In: Ford TE (ed) Aquatic microbiology. Blackwell Scientific Publications, Boston, p 289-320

Kogure K, Simidu U, Taga N (1979) A tentative direct microscopic method for counting living marine bacteria. Can J Microbiol 25:415-420

Krambeck C, Krambeck H, Overbeck J (1981) Microcomputer-assisted biomass determinations of planktonic bacteria on scanning electron micrographs. Appl Environ Microbiol 42:142-149

Laemmli UK (1970) Cleavage of structural proteins during the assembly of the head of bacteriophage T4. Nature 277: $680-685$
Lázaro B, Cárcamo J, Audícana A, Perales I, FernándezAstorga A (1999) Viability and DNA maintenance in nonculturable spiral Campylobacter jejuni cells after longterm exposure to low temperatures. Appl Environ Microbiol 65:4677-4681

Lleo MM, Tafi MC, Canepari P (1998) Nonculturable Enterococcus faecalis cells are metabolically active and capable of resuming active growth. Syst Appl Microbiol 21: 333-339

MacDonell MT, Colwell RR (1985) Phylogeny of the Vibrionaceae, and recommendation for two new genera, Listonella and Shewanella. Syst Appl Microbiol 6: 171-182

Magariños B, Romalde JL, Barja JL, Toranzo AE (1994) Evidence of a dormant but infective state of the fish pathogen Pasteurella piscicida in seawater and sediment. Appl Environ Microbiol 60:180-186

Marco-Noales E, Biosca EG, Amaro C (1999) Effects of salinity and temperature on long-term survival of the eel pathogen Vibrio vulnificus biotype 2 (serovar E). Appl Environ Microbiol 65:1117-1126

Mary P, Chihib NE, Charafeddine O, Defives C, Hornez JP (2002) Starvation survival and viable but nonculturable states in Aeromonas hydrophila. Microb Ecol 43:250-258

McDougald D, Rice SA, Weichart D, Kjelleberg S (1998) Nonculturability: adaptation or debilitation? FEMS Microbiol Ecol 25:1-9

Mizunoe Y, Wai SN, Ishikawa T, Takade A, Yoshida S (2000) Resuscitation of viable but nonculturable cells of Vibrio parahaemolyticus induced at low temperature under starvation. FEMS Microbiol Lett 186:115-120

Montes M, Pérez MJ, Nieto TP (1999) Numerical taxonomy of Gram-negative, facultative anaerobic bacteria isolated from skin of turbot (Scophthalmus maximus) and surrounding water. Syst Appl Microbiol 22:604-618

Mukamolova GV, Kaprelyants AS, Young DI, Young M, Kell DB (1998) A bacterial cytokine. Proc Natl Acad Sci 95: 8916-8921

Oliver JD (1993) Formation of viable but nonculturable cells. In: Kjelleberg $\mathrm{S}$ (ed) Starvation in bacteria. Plenum Press, New York, p 239-272

Oliver JD (2000) Problems in detecting dormant (VBNC) cells and the role of DNA elements in this response. In: Jansson JK, van Elsas JD, Bailey MJ (eds) Tracking geneticallyengineered microorganisms. Landes Bioscience, Georgetown, TX, p 1-15

Oliver JD, Hite F, McDougald D, Andon NL, Simpson LM (1995) Entry into, and resuscitation from, the viable but nonculturable state by Vibrio vulnificus in a estuarine environment. Appl Environ Microbiol 61:2624-2630

Pommepuy M, Butin M, Derrien A, Gourmelon M, Colwell RR, Cormier M (1996) Retention of enteropathogenicity by viable but nonculturable Escherichia coli exposed to seawater and sunlight. Appl Environ Microbiol 62(12): 4621-4626

Rahman I, Shahamat M, Kirchman PA, Russek-Cohen E, Colwell RR (1994) Methionine uptake and cytopathogenicigy of viable but nonculturable Shigella dysenteriae. Appl Environ Microbiol 60:3573-3578

Rahman MH, Suzuki S, Kawai K (2001) Formation of viable but non-culturable state (VBNC) of Aeromonas hydrophila and its virulence in goldfish (Carassius auratus). Microbiol Res 156:103-106

Ravel J, Knight IT, Monahan CE, Hill RT, Colwell RR (1995) Temperature-induced recovery of Vibrio cholerae from the viable but nonculturable state: growth or resuscitation. Microbiology 141:377-383 
Roszak DB, Colwell RR (1987) Survival strategies of bacteria in the natural environment. Microbiol Rev 51:365-379

Sack DA, Tackt CO, Cohen MB, Sack RB and 8 others (1998) Validation of a volunter model of cholera with frozen bacteria as a challenge. Infect Inmunol 66:1968-1972

Santos Y, Pazos F, Núñez S, Toranzo AE (1997) Antigenic characterization of Vibrio anguillarum-related organisms isolated from turbot and cod. Dis Aquat Org 28:45-50

Signoretto C, Lleo MM, Tafi MC, Canepari P (2000) Cell wall chemical composition of Enterococcus faecalis in the viable but nonculturable state. Appl Environ Microbiol 66: 1953-1959

Signoretto C, Lleo MM, Canepari P (2002) Modification of the peptidoglycan of Escherichia coli in the viable but nonculturable state. Curr Microbiol 44:125-131

Steinert M, Emödy L, Amann R, Hacker J (1997) Resuscitation of viable but nonculturable Legionella pneumophila Philadelphia JR32 by Acanthamoeba castellanii. Appl Environ Microbiol 63:2047-2053

Thorsen BK, Enger O, Norland S, Hoff KA (1992) Long-term

Editorial responsibility: David Karl,

Honolulu, Hawaii, USA starvation survival of Yersinia ruckeri at different salinities studied by microscopical and flow cytometric methods. Appl Environ Microbiol 58:1624-1628

Wai SN, Mizunoe Y, Yoshida S (1999) How Vibrio cholerae survive during starvation? FEMS Microbiol Lett 180: 123-131

Wai SN, Mizunoe Y, Takade A, Yoshida S (2000) A comparison of solid and liquid media for resuscitation of starvation-and low-temperature-induced nonculturable cells of Aeromonas hydrophila. Arch Microbiol 173:307-310

Weichart D, Kjelleberg S (1996) Stress resistance and recovery potential of culturable and nonculturable cells of Vibrio vulnificus. Microbiology 142:845-853

Weichart D, Oliver JD, Kjelleberg S (1992) Low temperature induced nonculturability and killing of Vibrio vulnificus. FEMS Microbiol Ecol 100:205-210

Zimmermann R, Iturriaga R, Becker-Birck J (1978) Simultaneous determination of the total number of aquatic bacteria and the number thereof involved in respiration. Appl Environ Microbiol 36:926-935

Submitted: September 27, 2002; Accepted: August 17, 2003 Proofs received from author(s): October 31, 2003 